Niyazi Ismayilov,

Ph.D, Associate Professor, Azerbaijan State University of Economics, Republic of Azerbaijan

iD ORCID ID, 0000-0002-2782-864,

email: niyazi.ismayilov@unec.edu.az

Correspondence author: niyazi.ismayilov@unec.edu.az

\title{
INNOVATIVE APPROACHES IN THE ACCOUNTING AND AUDIT OF THE BOOK VALUE OF ASSETS: BIBLIOMETRIC ANALYSIS
}

Abstract. The paper deals with the analysis on the innovative approaches in the accounting and audit of the book value of assets. The results of analyses proved that of the book value of assets in the accounting and audit, especially in the context of financial crises, implementation of the new or modified standard of accounting and reporting becomes an important part of the issues. Herewith, financial and management decision, which compare book and market value, trying to predict the future (fair) value of assets or even a company (firm). The main goal of the paper is analysed of the tendency in the scientific literature on the accounting and audit of the book value of assets to identify future research directions. For the analysis, the VOSviewer and Scopus tools were used. This study reviews 714 papers from the Scopus database. The time for analysis was all timeline of the Scopus database. The results showed the growing tendency in publishing the documents in the Scopus database focused on the accounting and audit of the book value of assets issues. It began to increase from 1997 to 1999, from 2007 to 2009, and from 2014 to 2017. Moreover, the focus of investigation moved from general issues to problem of the fair value of assets, implementation of modifying standards of reporting and accounting. In 2018, the number of documents increased by $1225 \%$ compared to 1997. It was the year with the biggest number of paper devoted to analysing the innovative approaches in the accounting and audit of the book value of assets. Mostly the innovative approaches in the accounting and audit of the book value of assets were analysed under the subject area as follows: Business, Management and Accounting; Economics, Econometrics and Finance; Social Sciences; Engineering. Besides, the biggest share of the scientists which investigated issues the innovative approaches in the accounting and audit of the book value of assets was from the USA, United Kingdom, Australia and China. In 2019 papers focused on analyses of the innovative approaches in the accounting and audit of the book value of assets were published in journals with high impact factor as follows: Contemporary Accounting Research, Accounting Review, International Journal of Accounting, Managerial Finance, Accounting And Business Research. Such results proved that theme on the innovative approaches in the accounting and audit of the book value of assets is actually in the ongoing trends of the modern accounting, finance, management and audit. The findings from VOSviewer identified 6 clusters of the papers which investigated innovative approaches in the accounting and audit of the book value of assets from the different points of views. The first most significant cluster merged the keywords as follows: accounting information, fair value, financial reporting, fair value accounting, firm value, intangible assets, intellectual capital etc. The second biggest cluster merged the keywords as follows: costs, cost accounting, accounting method, assets value, assets valuation, depreciation, cost-benefit analyse, balance sheet etc. The third biggest cluster focused on criminal aspects of value relevance, book value, the book value of equity, equity valuation, earnings, dividend etc. Such tendency allows making a conclusion, financial and management decision, which compare book and market value, trying to predict future (fair) value of assets or even a company (firm) are very close and popular in different issues.

Keywords: book value, asset value, accounting, financial accounting, audit, innovative approaches.

Introduction. Scandals involving fraudulent reporting by heads of well-known companies arise in different countries. Thus, in 2001, the United States a court was held concerning the bankruptcy of the energy company Enron. The result of the company bankruptcy was more than $\$ 60$ billion in the value of securities, almost $\$ 2.1$ billion in pension payments were lost, and 5.6 thousand people lost their jobs. 11

Cite as: Ismayilov, N. (2020). Innovative Approaches in the Accounting and Audit of the Book Value of Assets: Bibliometric Analysis. Marketing and Management of Innovations, 3, 319-331. http://doi.org/10.21272/mmi.2020.3-23 
billion dollars in 2002 was a loss from fraudulent accounting of WorldCom. 1.22 billion dollars was a loss from misstatement of reporting by Toshiba. In 2011, a scandal broke out with the Olympus company, in which the management covered up accounting manipulations. And there are a lot of such examples in the countries of the former Soviet Union. An anthology of creative accounting techniques, among the main approaches to accounting fraud, highlight the overestimation of assets. Therefore, the topic of innovative approaches in the accounting and audit of the book value of assets is relevant. The terminology in accounting related to the book value of assets is used more frequently during financial crises, both by academics and accounting/audit professionals. In this paper, a literature review was performed regarding the use and the connections of terminology, the book value of assets issues. First, the study aims to summarise the level of knowledge of the innovative approaches in the accounting and audit of the book value of assets. A second aim is to correlate published material regarding the accounting and audit of the book value of assets to answer the question regarding that terminology have strong connections with the fair valuation of assets. Thus, at the first stage, the definition, principals and features of the book value of assets should be defined. It should be noted, that traditionally the book value of assets analysed with market value and management. The first mention of the book value of assets can be attributed to the publications of the founders of modern accounting Benedetto Cotrugli (Cotrugli, 1458) and Luka Pacioli (Pacioli, 1494). In whose papers the first mentions of the procedure for filling out the loss and profit account are published, and the balance should be transferred to the capital account, described some new methods (double-entry bookkeeping, trial balances, balance sheets etc.), that still used in accounting, also the «rule of 72» for predicting an investment's future value was presented. Although that, the huge range of modern scientists in the papers analysing the approaches in the accounting and audit of the book value of assets, do so in the context of financial crises, implementation of new or modify standard of accounting etc. We used selective criteria like articles published in Scopus. Finally, the paper proposes that as a future study, we ought to analyses the link between book value, market value, financial, accounting and report standards etc.

Literature review. Often the widespread use of accounting terminology of the book value of assets in academic literature is linked with the development of national and international financial, accounting, audit and reporting standards and requirement of their implementation.

The oldest publication, which focused on the innovative approaches in the accounting and audit of the book value of assets, according to Scopus database, what can be found, was published in 1931, this is paper (Blackburn, 1931). In this article, the authors considered obsolescence as concerning the economic value of a machine regardless of its physical condition or age. There are presented the advantages of the standardised system of cost accounting developed by the National Machine Tool Builders' Association and being adopted by many machine-tool builders in the USA. In addition, the paper attention was called to a feature of the standardised accounting system, which discloses short-time utilisation of any machine. This paper started a big wave of publications, which is devoted to the introduction of accounting and reporting standards. The next oldest paper (Hillman, 1970) described four trends that are likely to develop. It discusses how the executive can minimise the negative impact of the changes, which have been made by the Accounting Principles Board for business combinations. Thus, one restricts those combinations that can be accounted for as a «pooling of interests». In turn, the other requires amortisation of the excess of the acquired company's purchase price over its adjusted book value. The newest study presented in the article (Wang et al., 2019) examines the effect of net income, the book value of equity, and comprehensive income on the value relevance of companies listed in the Taiwan stock markets after adopting IFRS. A separate area of research is human resource accounting in firms and companies. The first paper in this sphere (Ansari et al., 1978) defined that focusing narrowly upon financial accounting and purposing to reflect the asset value of people on financial statements is a common misconception about human resource accounting. Instead of that, the authors proposed to consider the major purpose of human resource accounting - to provide concepts and measurements to facilitate the effective and efficient management of human resources. Also in the paper 
the main determinants of the human resource accounting were defined: rationality and multidisciplinary problemsolving approaches which characterise management science was applied to human resource accounting and economic and social factors of the 1960s. The newest article (Kwon, 2019) investigates how investment in developing human capital can help promote corporate value. The empirical results of the article show that the book value of equity, education and training expenses and welfare costs has positive relationships with enterprise value. In contrast, accounting earnings have significantly negative effects on them.

The next area of publications is discussing the difference in financial market data and accounting data. The oldest article on «financial data vs accounting data» (Pike et al., 1988) analysed the accounting and other data drawn from 185 actual unlisted share valuation reports within seven major Canadian accounting firms. It was to estimate a model of and to explain variations in the values placed on unlisted shares and found that valuation of unlisted shares can be explained largely in terms of historical accounting data, the main sources being earnings, earnings stability and asset book value. The most recent paper in this area indexed by the Scopus database (Belesis, 2020) presented the comparison of how the financial market and accounting data affect stock prices and returns. Authors tried to answer the question of whether financial information or accounting data dominate in evaluating stock prices, and estimated share prices based on financial data using the capital asset pricing model and for accounting data, using Ohlson's model. Another sphere of research is the digitalisation of accounting. The first paper in this sphere according to the Scopus database, is an article in «Computers and Industrial Engineering» (Smith, 1986). It was published in 1986 and presented a computerised lease-versus-buy program utilised by the Defense Contract Audit Agency to monitor defense contractor data processing hardware procurement. The main points of the paper shall pertain to the financial elements incorporated into the software, reports generated, and the resulting lease-versus-buy decision. The newest is paper (Meegoda et al., 2017) presented integrated drainage information, analysis and management system was developed and implemented for the New Jersey Department of Transportation. Attention focused on significant performance feature of is its proactive nature, which affords decision-makers the means of conducting a comprehensive financial analysis to determine the optimal proactive schedule for the proper maintenance actions and to prioritise them accordingly. Also, benefits of the system were mentioned, which include long-term savings that accrue by adopting optimised preventive maintenance strategies and facilitating compliance with Governmental Accounting Standards Board and federal stormwater regulations.

A part of issues devoted to problem of personality of accountant or auditor and result of their activity. The oldest article in the Scopus database is (Shields et al., 1998). This paper describes an experiment which measured the effects of alternative sample space representations on the accuracy of auditors' uncertainty judgments for an account requires a focus on either possible audit values or possible book value misstatements, reasons for and implications of this result are discussed. The most recent paper on data of research (Church et al., 2019)contended that in China, narcissistic characteristics fuel auditors' competitiveness and embolden them to stand firm in negotiations. Moreover, it lengthens the negotiation process potentially but leading to more conservative negotiation outcomes. In turn, the narcissistic auditors negotiate reported asset values that reflect less aggressive reporting choices. The data was collected using three different research methods as follows: analysis of archival data; interviews with practicing audit partners; experiments.

With the growth of interest to the indicator of sustainable development appeared issues devoted to accounting and audit of the value of environmental resources. The first paper in this area (Edwards, 2005) discussed the problem of environmental accounting methods (The Current Rent Method II). That was used to estimate resource rent and the asset value of resource biomass in the U.S. Atlantic sea scallop fishery during 1977-2002: high levels of producer surplus and profit masked led to negative asset values after many years of resource depletion and degradation by the overcapitalised fishery; low effect of regulatory policies (involving limited entry, vessel effort quotas, and area closures) at any benchmark interest rate on 
growth of asset value. Authors proposed new methods: adjusting fishery resource accounts for inframarginal rent as well (as the value of vessel capital) as are property rights to the resource income component of so-called «producer» surplus. The newest paper (Guo et al., 2019) presented the research status of carbon asset value assessment and ecological compensation. It analysed and summarised the applicability of the ecological environment compensation value accounting method. Further, it integrated environmental accounting to construct the ecological value compensation index, and built the ecological basis accordingly and carbon asset assessment model from the perspective of compensation. The findings proved, that despite colossal range investigations on the innovative approaches in the accounting and audit of the book value of assets from different points of views this problem had not analysed yet considering various aspects of the accounting. In this case, this paper aimed to analyse the tendency in the scientific literature on the innovative approaches in the accounting and audit of the book value of assets to identify future research directions.

Methodology and research methods. The main hypothesis of investigation is cheeking the increasing tendency on analysing of the innovative approaches in the accounting and audit of the book value of assets issues by the scientists. For this purpose, according to the paper (Vasylieva et al., 2020), the investigation was done in the following scheme:

1. Identifying the tendency of papers focused on the analyses of the innovative approaches in the accounting and audit of the book value of assets.

2. Allocating the main subject areas under analyses of the innovative approaches in the accounting and audit of the book value of assets issues.

3. Identifying the most citation papers and Journals, which contained the papers on the innovative approaches in the accounting and audit of the book value of assets.

4. Clustering the papers on the main directions for investigations with the purpose to identify the further options for analyses.

For the analysis, the following keywords were chosen: book value, asset value, accounting, financial accounting and audit. This study reviewed 714 papers from Scopus. The time for analysis was all timeline of the Scopus database. The analyse was done by using the software of VOSviewer and Scopus analyses. Thus, VOSviewer allows to allocate and visualise the network of definitions which used and co-citation during the investigation of the innovative approaches in the accounting and audit of the book value of assets issues. Scopus tools allowed to analyse the publication towards different parameters: affiliation, source title (journal title), number of citation, amount of the papers, funding, the subject area etc. Thus, according to information from VOSviewer site in the network visualisation of VOSviewer allow to allocate and visualise the scientific direction which has strong relationships. The closer keywords are located to each other, the stronger their relations.

Results. The findings of analysing proved that the numbers of paper which focused on the innovative approaches in the accounting and audit of the book value of assets in the database Scopus has been steadily increasing over the whole analysed period. The average growth rate was $25 \%$. Thus, this database shows a significant growth rate of publications from 1997 to 1999, from 2007 to 2009 and from 2014 to 2017. This could be justified by the widespread problems associated with the active discussion of the problem of the changes in the value relevance of equity book value and assets value during a crisis period, implementation of international financial report standard etc. In 2018, the number of papers analysed accounting and audit of the book value of assets was increased by $1225 \%$ compared with the 1997 (Figure 1). 


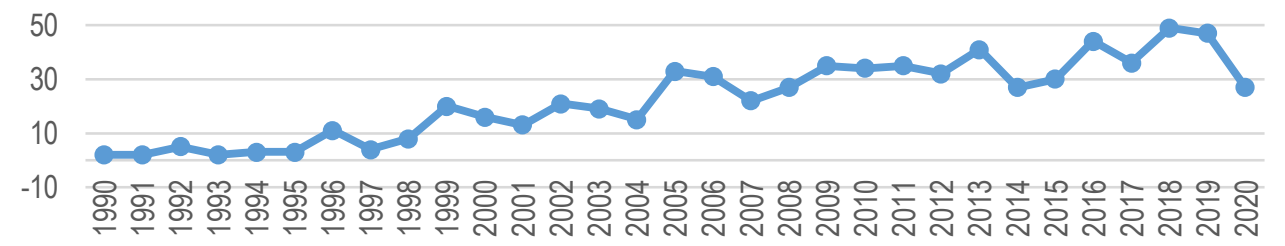

Figure 1. The number of documents in Scopus which contain accounting and audit of the book

Sources: developed by the authors. value of assets issues in 1990-2020.

The findings proved (Figure 2) that the innovative approaches in the accounting and audit of the book value of assets were analysed according to data of Scopus in the framework of the subject area as follows: Business, Management and Accounting - 40,76\%; Economics, Econometrics and Finance - 31,05\%; Social Sciences - 6,45\%; Engineering - 4,06\%; and others (Decision Sciences, Environmental Science, Computer Science, Agricultural and Biological Sciences, Mathematics etc.) - 17,68\%.

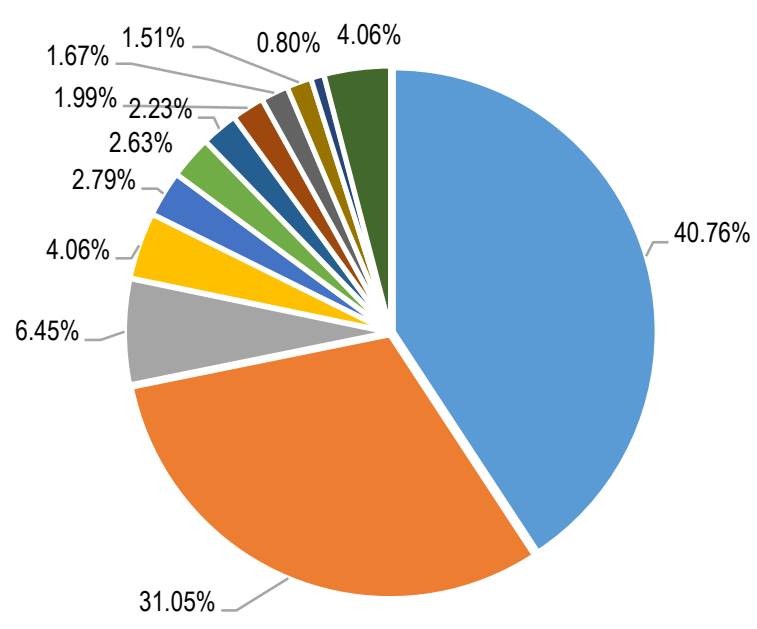

$$
\begin{aligned}
& \text { - Business, Management and } \\
& \text { - Accounting } \\
& \text { - Economics, Econometrics and } \\
& \text { Finance } \\
& \text { - Social Sciences } \\
& \text { - Engineering } \\
& \text { - Decision Sciences } \\
& \text { - Environmental Science } \\
& \text { - Computer Science } \\
& \text { - Agricultural and Biological Sciences } \\
& \text { - Mathematics } \\
& \text { - Energy } \\
& \text { - Earth and Planetary Sciences } \\
& \text { - Other }
\end{aligned}
$$

Figure 2. The subject area in Scopus for analysing the accounting and audit of the book value of

Sources: compiled by the authors.

The analysis by country showed that mostly the scientist with the USA, United Kingdom, Australia and China affiliations investigated the accounting and audit of the book value of assets issues. The top 20 countries' affiliation of the scientists which investigated the accounting and audit of the book value of assets issues according to Scopus database showed in Figure 3. Figure 3 also shows the number of publications from these countries in the Scopus database.

Besides, considering the findings from Scopus in 2019 the high ranked Accounting Review, Research In International Business And Finance, Benchmarking, Ecosystem Services, Management Science Letters began to publish more papers on the innovative approaches in the accounting and audit of the book value of assets issues (Table 1). 


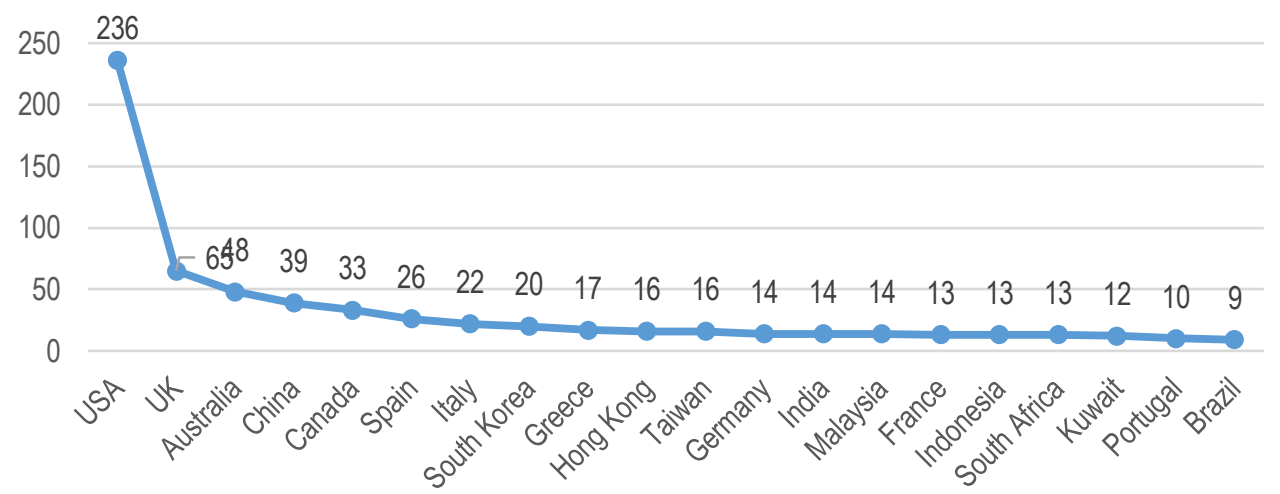

Figure 3. Top 20 country's affiliation of the scientists which investigated the accounting and audit of the book value of assets issues

Sources: developed by the authors.

Table 1. The top 5 Journal, indexed by Scopus, which published the papers on the innovative approaches to accounting and audit of the book value of assets

\begin{tabular}{|c|c|c|c|c|c|}
\hline Title of the Journal & Covered by Scopus & $\begin{array}{c}\text { CiteScore } \\
2019 \\
\end{array}$ & $\begin{array}{l}\text { SJR } \\
2019 \\
\end{array}$ & SNIP 2019 & $\begin{array}{c}\text { Numbers of the } \\
\text { papers }\end{array}$ \\
\hline \multirow{5}{*}{$\begin{array}{l}\text { Contemporary Accounting } \\
\text { Research } \\
\text { Accounting Review } \\
\text { International Journal Of } \\
\text { Accounting } \\
\text { Managerial Finance } \\
\text { Accounting And Business } \\
\text { Research }\end{array}$} & 1984 to Present & 4.3 & 2.207 & 2.274 & 23 \\
\hline & 1996 to Present & 7.1 & 5.446 & 3.729 & 20 \\
\hline & 1996 to Present & 2.9 & 0.450 & 1.259 & 17 \\
\hline & 1996 to Present & 1.2 & 0.248 & 0.658 & 14 \\
\hline & 1970 to Present & 3.9 & 0.863 & 1.513 & 13 \\
\hline
\end{tabular}

Sources: developed by the authors.

According to the Scopus database, all 10 the most cited papers were published by the high ranked Journals. The most cited papers were published by the scientist Ohlson, J.A. in 1995 in Contemporary Accounting Research (Ohlson, 1995) (Table 2). Moreover, he is the author of the famous Ohlson model. It is the best known of the models of value relevance aimed at formalising the relationship between accounting values and firm value, which cited by Scopus ranking journal 2047 times (Table 2). In this paper, the author developed and analysed a model of a firm's market value as it relates to contemporaneous and future earnings, book values, and dividends. Two owners' equity accounting constructs provide the underpinnings of the model: the clean surplus relation applies, and dividends reduce current book value but do not affect current earnings. The model satisfies many appealing properties, and it provides a useful benchmark when one conceptualises how market value relates to accounting data and other information. The findings from VOSviewer identified 6 clusters of the papers which investigated the approaches to accounting and audit of the book value of assets from the different points of views (Figure 4). The first biggest cluster (red cluster) merged the paper, which contained the keywords as follows: accounting information, fair value, financial reporting, fair value accounting, firm value, intangible assets, intellectual capital etc. (Figure 5). The second biggest cluster (green cluster) 
contained such issues as follows: costs, cost accounting, accounting method, assets value, assets valuation, depreciation, cost-benefit analyse, balance sheet etc. (Figure 6).

Table 2. The most cited papers on the accounting and audit of the book value of assets 19312020 according to Scopus database

\begin{tabular}{|c|c|c|c|}
\hline Authors and Title & Year & Source title & Cited \\
\hline $\begin{array}{l}\text { Ohlson, J. A. Earnings, Book Values, and } \\
\text { Dividends in Equity Valuation } \\
\text { Feltham, G. A., Ohlson, J. A. Valuation and } \\
\text { Clean Surplus Accounting for Operating and } \\
\text { Financial Activities } \\
\text { Amir, E., Lev, B. Value-relevance of nonfinancial } \\
\text { information: The wireless communications } \\
\text { industry } \\
\text { Dechow, P. M., Hutton, A. P., Sloan, R. G. An } \\
\text { empirical assessment of the residual income } \\
\text { valuation model } \\
\text { Hawawini, G., Subramanian, V., Verdin, P. Is } \\
\text { performance driven by industry - or firm-specific } \\
\text { factors? A new look at the evidence } \\
\text { Barton, J., Simko, P.J. The balance sheet as an } \\
\text { earnings management constraint } \\
\text { Hung, M., Subramanyam, K.R. Financial } \\
\text { statement effects of adopting international } \\
\text { accounting standards: The case of Germany } \\
\text { Beaver, W. H., Ryan, S. G. Conditional and } \\
\text { unconditional conservatism: Concepts and } \\
\text { modelling } \\
\text { Erel, I., Liao, R. C., Weisbach, M. S. } \\
\text { Determinants of Cross-Border Mergers and } \\
\text { Acquisitions } \\
\text { Nelson, K. K. Fair value accounting for } \\
\text { commercial banks: An empirical analysis of } \\
\text { SFAS No. } 107\end{array}$ & $\begin{array}{l}2002 \\
2007\end{array}$ & $\begin{array}{c}\text { Contemporary Accounting } \\
\text { Research } \\
\text { Contemporary Accounting } \\
\text { Research } \\
\text { Journal of Accounting and } \\
\text { Economics } \\
\text { Journal of Accounting and } \\
\text { Economics } \\
\text { Strategic Management Journal } \\
\text { Accounting Review } \\
\text { Review of Accounting Studies } \\
\text { Review of Accounting Studies }\end{array}$ & 301 \\
\hline
\end{tabular}

Sources: developed by the authors.

The third biggest cluster (blue cluster) focused on: value relevance, book value, the book value of equity, equity valuation, earnings, dividend etc. The fourth-biggest cluster (the yellow one) merged the paper, which contained the keywords as follows: book value, market value, risk assessment, risk analyse, bank, IFRS, Ohlson model, accountability, goodwill etc. Next cluster (purple) located close to the second one (green), yellow cluster (book vs marked valuation) and red (fair value accounting) contained such issues as follows: accounting, economics, management, financial management, management accounting, economic aspect etc. They are connected through the word «accounting/financial management - book value/IFRS - cost accounting/ asset management - equity valuation/financial report». The closer location of the abovementioned cluster to each other proved the stronger their relations. Such tendency allows making a conclusion, financial and management decision, which compare book and market value, trying to predict future (fair) value of assets or even a company (firm) are very close and popular in different issues. The findings proved that financial management is the customer of accounting information. 


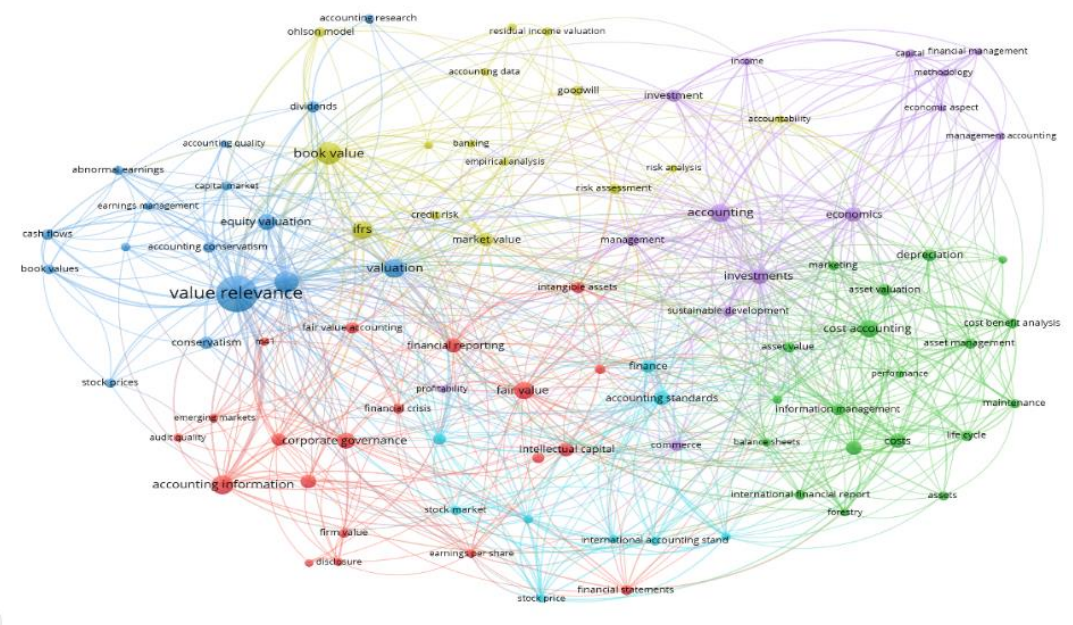

Figure 4. The network visualisation of the co-citation of the papers on the innovative approaches to accounting and audit of the book value of assets issues

Sources: developed by the authors using the Scopus database and VOSviewer tool.

Still, there are problems of fair value (taking into account investment and economic aspects), fair valuation of assets (compliance of the book value with the market value), compliance with accounting standards, etc. This is the case why problem «book value vs market value» become an important part of issues on the innovative approaches to accounting and audit of the book value of assets (Figure 7).

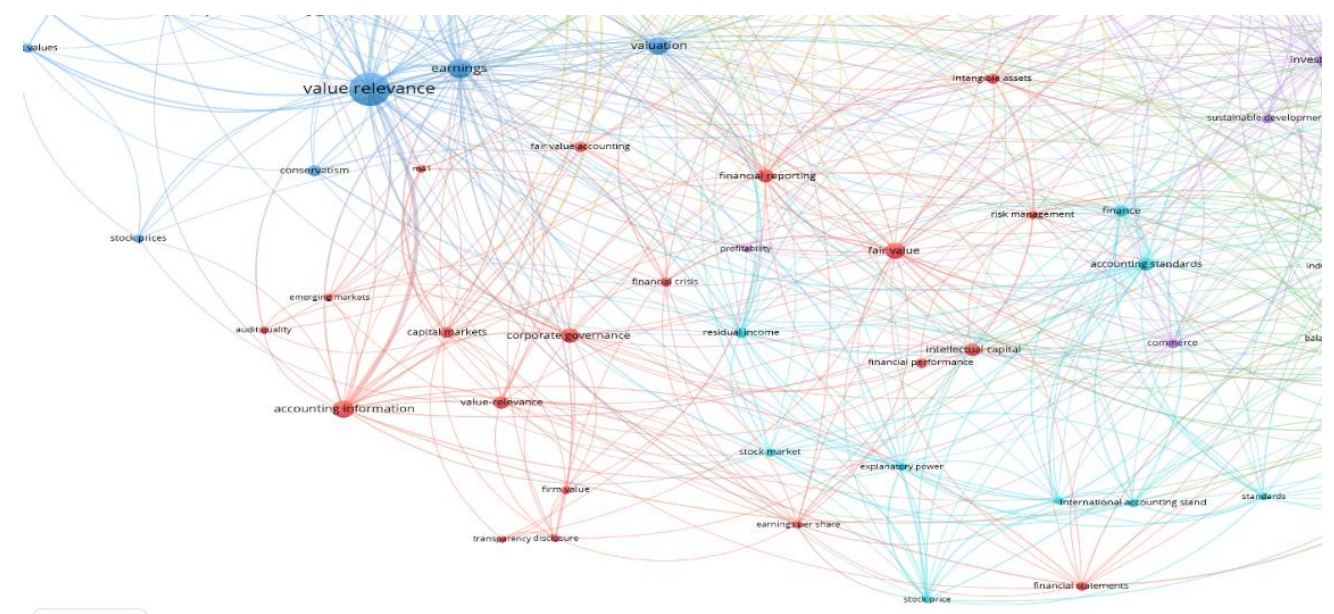

Figure 5. The network visualisation of the co-citation of the papers on the innovative approaches to accounting and audit of the book value of assets (red cluster with close areas)

Sources: developed by the authors using the Scopus database and VOSviewer tool. 


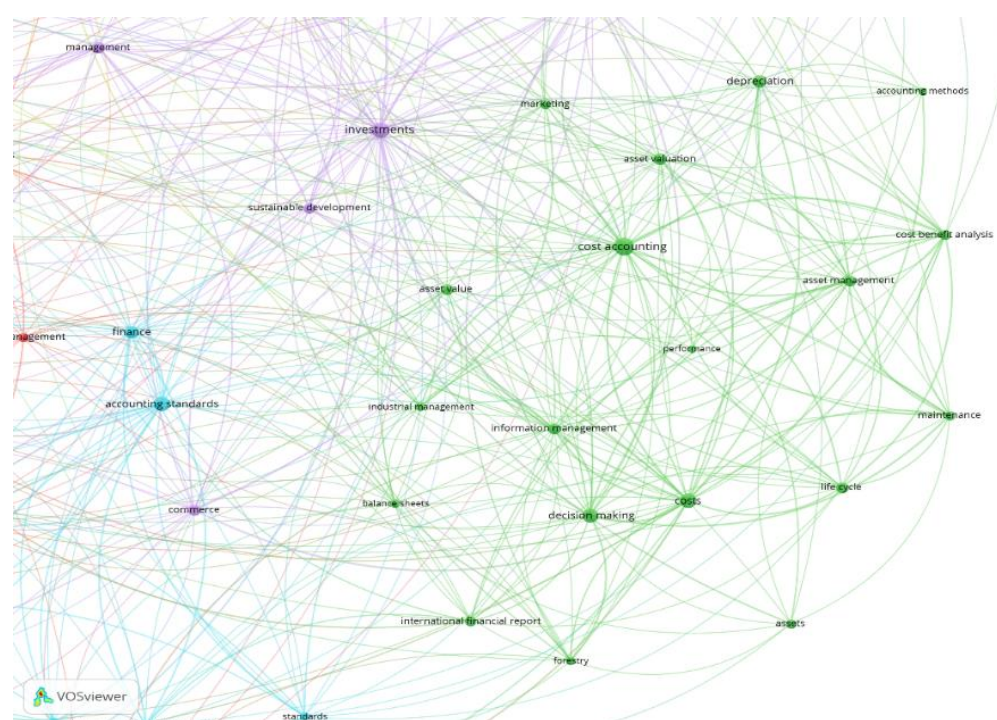

Figure 6. The network visualisation of the co-citation of the papers on the innovative approaches to accounting and audit of the book value of assets issues (green cluster with close areas) Sources: developed by the authors using the Scopus database and VOSviewer tool.

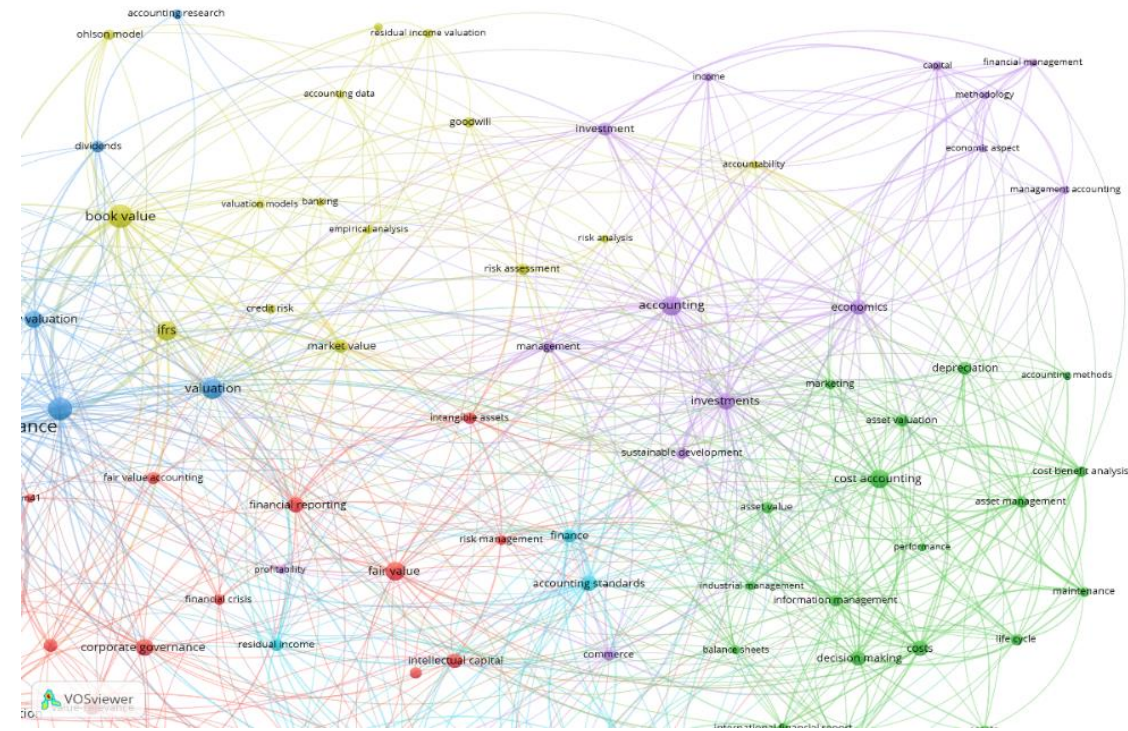

Figure 7. The network visualisation of the co-citation of the keywords on purple clusters Sources: developed by the authors using the Scopus database and VOSviewer tool.

The next small cluster turquoise (accounting standard) also located close to tow bigger clusters - red and green ones. It allows concluding that accounting standard is very close connected with fair financial reports and value and with cost and information management (Figure 8). 


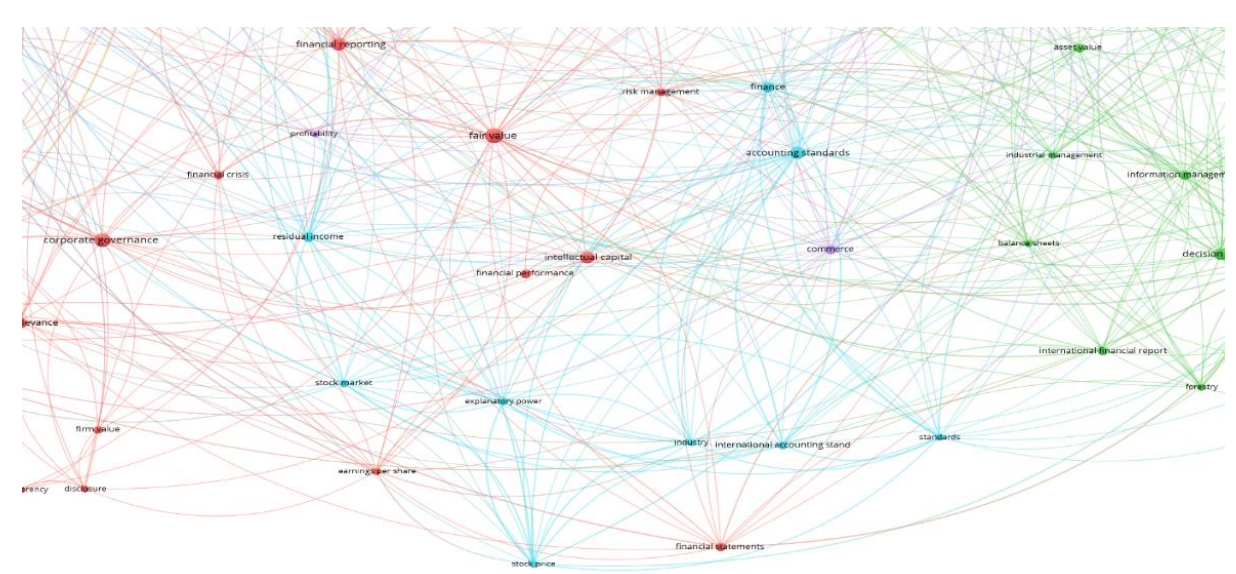

Figure 8. The network visualisation of the co-citation of the keywords on turquoise, red and green clusters

Sources: developed by the authors using the Scopus database and VOSviewer tool.

Thus, at the next stage, it was provided with an in-depth analysis of the co-citations on the innovative approaches to accounting and audit of the book value of assets issues in third and fourth biggest clusters. The keywords were chosen as follows: abnormal earning, earning, credit risk, cash flow, residual income value. The findings showed in Figure 9. The findings proved the research hypothesis. Thus, it is a very popular topic on the valuation of assets basing on future incomes or trends, basing on accounting information in the papers analysed the accounting and audit of the book value of assets issues, especially in connection with bank credit risks analyse.

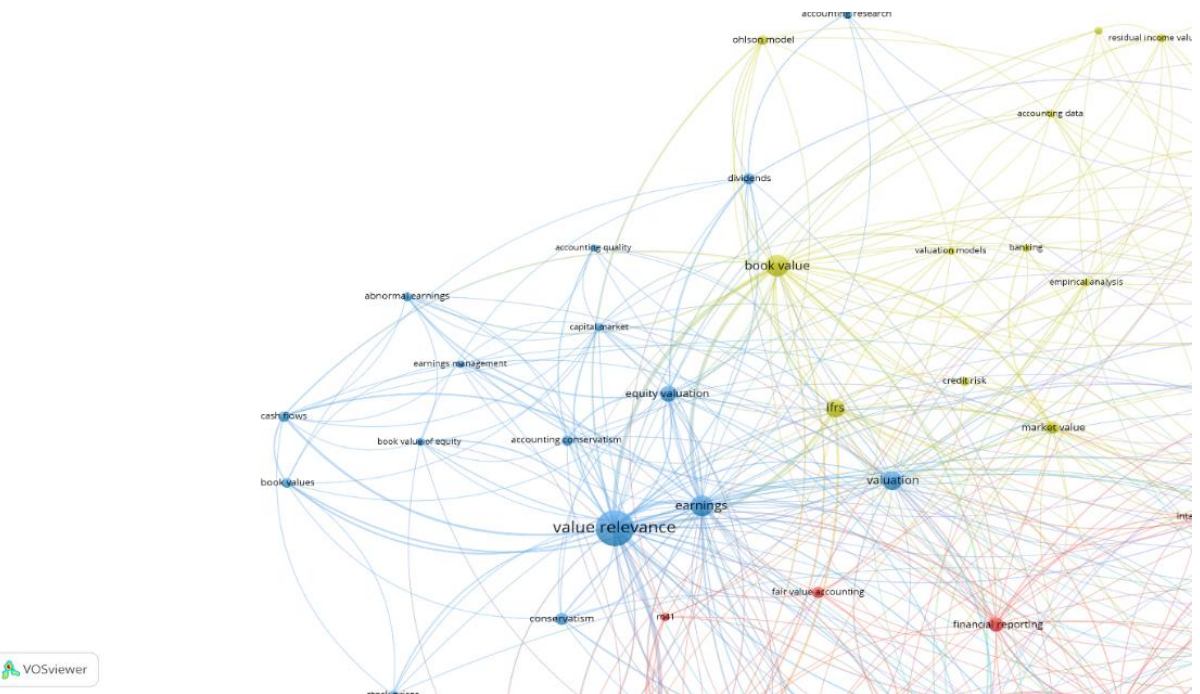

Figure 9. The network visualisation of the co-citation of the keywords on blue and yellow clusters Sources: developed by the authors using the Scopus database and VOSviewer tool. 
Considering the results, 6 clusters. The biggest was red, green, blue and yellow. In this case, the red cluster contained keywords as follows: relating to offences related to fair valuation. Thus, the findings proved the research hypothesis that the topic of fair valuation of assets and correct reflection of them in the balance sheet in the papers which analysed approaches to using the book value of assets in bank credit risks analyses are very popular. At the same time, the most related areas with a book value of assets were accounting standards, cost analyses, value relevance.

Conclusion. The results of the analysis proved that the innovative approaches to accounting and audit of the book value of assets issues are a popular direction for investigation which formed in separate scientific school. Besides, the quantity of paper become increased during and several years after crises and after appearing of requirements to implement new accounting standards. The findings from VOSviewer allow allocating 6 clusters. All of them have a close relationship. In turn, the first biggest cluster relates to offences concerning the fair value of assets and corporative governance. The second biggest cluster merged the keywords as follows: costs, cost accounting, accounting method, assets value, assets valuation, depreciation, cost-benefit analyse, balance sheet etc. The third biggest cluster focused on value relevance, book value, the book value of equity, equity valuation, earnings etc. The fourth-biggest cluster (the yellow one) merged the paper which related to a different model of valuation of assets (Ohlson, bank, risk, etc.). Such tendency allows concluding that triangles «accounting/financial management - book value/IFRS - cost accounting/ asset management - equity valuation/financial report» become important parts of the topic - the innovative approaches to accounting and audit of the book value of assets.

\section{References}

Akhundova, N., Pimonenko, T., \& Us, Y. (2020). Sustainable growth and country green brand: visualization and analysis of mapping knowledge. Economic and Social Development: Book of Proceedings, 234-243. [Google Scholar]

Amir, E., \& Lev, B. (1996). Value-relevance of nonfinancial information: The wireless communications industry. Journal of accounting and economics, 22(1-3), 3-30. [Google Scholar] [CrossRef]

Ansari, S. L., \& Flamholtz, D. T. (1978). Management science and the development of human resource accounting. Accounting Historians Journal, 5(2), 11-35. [Google Scholar] [CrossRef]

Baranovskyi, O. I. (2020). Regulation of functional and structural transformational processes in the financial sector. Financial and credit activity: problems of theory and practice, 1(32), 292-306. [Google Scholar] [CrossRef]

Baranovskyi, O. I. (2018). Quality of the transformational processes in the financial sector of the national economy: vectors of the measurement. Financial and credit activity: problems of theory and practice, 3(26), 350-367. [Google Scholar] [CrossRef]

Barton, J., \& Simko, P. J. (2002). The balance sheet as an earnings management constraint. The accounting review, 77(s-1), 1-27. [Google Scholar] [CrossRef]

Beaver, W. H., \& Ryan, S. G. (2005). Conditional and unconditional conservatism: Concepts and modeling. Review of accounting studies, 10(2-3), 269-309. [Google Scholar] [CrossRef]

Belesis, N., Sorros, J., \& Karagiorgos, A. (2020). Financial Market Data Versus Accounting Data: Which Better Explains Stock Returns?. International Advances in Economic Research, 1-14. [Google Scholar] [CrossRef]

Bilan, Y., Pimonenko, T., \& Starchenko, L. (2020). Sustainable business models for innovation and success: bibliometric analysis. In E3S Web of Conferences (Vol. 159, p. 04037). EDP Sciences [Google Scholar]

Blackburn, L. A., Brussel, J. W., \& Fors, A. R. (1931). Controlling Factors in Machine-Tool Obsolescence (No. 310045). SAE Technical Paper. [Google Scholar] [CrossRef]

Boiarko, I. M. (2016). Praxeological and situational approaches in the formation of strategic accounting. Financial and credit activities: problems of theory and practice, 2(21), 80-90. [Google Scholar] [CrossRef]

Church, B. K., Dai, N. T., Kuang, X., \& Liu, X. (2019). The Role of Auditor Narcissism in Auditor-Client Negotiations: Evidence from China. Contemporary Accounting Research. [Google Scholar] [CrossRef]

Cotrugli, B. (1458). Della mercatura et del mercante perfetto: Scritti gia piu di anni CX. et hora dati in luce; Utilissimi ad ogni mercante. Elefanta. [Google Scholar]

Dechow, P. M., Hutton, A. P., \& Sloan, R. G. (1999). An empirical assessment of the residual income valuation model. Journal of accounting and economics, 26(1-3), 1-34. [Google Scholar] [CrossRef] 


\section{N., Ismayilov. Innovative Approaches in the Accounting and Audit of the Book Value of Assets: Bibliometric Analysis.}

Edwards, S. (2005). Accounting for rents in the US Atlantic sea scallop fishery. Marine Resource Economics, 20(1), 61-76. [Google Scholar]

Erel, I., Liao, R. C., \& Weisbach, M. S. (2012). Determinants of cross-border mergers and acquisitions. The Journal of finance, 67(3), 1045-1082. [Google Scholar] [CrossRef]

Feltham, G. A., \& Ohlson, J. A. (1995). Valuation and clean surplus accounting for operating and financial activities. Contemporary accounting research, 11(2), 689-731. [Google Scholar] [CrossRef]

Guo, Z., \& Huang, S. (2019). Research on carbon asset value evaluation based on ecological compensation perspective. Paper presented at the Conference Proceedings of the 7th International Symposium on Project Management, ISPM 2019, 812-817.

Hawawini, G., Subramanian, V., \& Verdin, P. (2003). Is performance driven by industry-or firm-specific factors? A new look at the evidence. Strategic management journal, 24(1), 1-16. [Google Scholar] [CrossRef]

Hillman, R. H. (1970). New accounting rules and acquisition planning: Negative effect of changes can be minimised. Business Horizons, 13(5), 71-78. [Google Scholar] [CrossRef

Hrytsenko, L. L., Roienko, V., \& Boiarko, I. M. (2018). Institutional background of the role of state in investment processes activation. Financial and credit activities: problems of theory and practice, 1(24), 338-344. [Google Scholar] [CrossRef]

Hung, M., \& Subramanyam, K. R. (2007). Financial statement effects of adopting international accounting standards: the case of Germany. Review of accounting studies, 12(4), 623-657. [Google Scholar] [CrossRef]

Kamata, H. (2016). A Segmentation Analysis of Japanese Spa Tourists. Journal of Tourism \& Services, 7(12). [Google Scholar]

Khan, K. A., Cera, G., \& Netek, V. (2019). Perception of the selected business environment aspects by service firms. Journal of Tourism and Services, 10(19), 111-127. [Google Scholar] [CrossRef]

Kuznyetsova, A. Y., \& Klishchuk, O. V. (2017). Theoretical conception of price stability targeting arrangement: investigation of basic principles of implementation monetary regime. Financial and credit activity: problems of theory and practice, 2(23), 388-396. [Google Scholar] [CrossRef]

Kwon, G. J. (2019). The Impact of Human Resource Expenses on Business Value: Focus on Welfare and Training Expenses in Listed Korean Stock Markets. Global Business Review, 20(3), 668-683. [Google Scholar] [CrossRef]

Meegoda, J. N., Juliano, T. M., Potts, L., Tang, C., \& Marhaba, T. (2017). Implementation of a drainage information, analysis and management system. Journal of Traffic and Transportation Engineering, 4(2), 165-177. [CrossRef]

Mura, L., \& Kajzar, P. (2019). Small Businesses in Cultural Tourism in a Central European Country. Journal of Tourism and

Services, 10(19), 40-54. [Google Scholar] [CrossRef]

Nelson, K. K. (1996). Fair value accounting for commercial banks: An empirical analysis of SFAS No. 107. Accounting Review, 161-182. [Google Scholar]

Ohlson, J. A. (1995). Earnings, book values, and dividends in equity valuation. Contemporary accounting research, 11(2), 661 687. [Google Scholar] [CrossRef]

Pacioli, L. (1994). Summa de Arithmetica geometria proportioni: et proportionalita. Paganino de paganini. [Google Scholar]

Pike, R., Sharp, J., \& Kantor, J. (1988). The role of accounting information in valuing unlisted shares. Accounting and Business Research, 18(71), 249-255. [Google Scholar] [CrossRef]

Rekunenko, I. I., Hrytsenko, L. L., Boiarko, I. M., \& Kostyrko, R. A. (2019). Financial debt market in the system of indicators of development of the economy of the country. Financial and credit activities: problems of theory and practice, 2(29), 430-439. [Google Scholar]

Shields, M. D., Solomon, I., \& Waller, W. S. (1987). Effects of alternative sample space representations on the accuracy of auditors' uncertainty judgments. Accounting, Organisations and Society, 12(4), 375-385. [Google Scholar] [CrossRef]

Smith, D. E. (1986). Microcomputer-based software to perform lease versus buy analysis. Computers \& Industrial Engineering, 11(1-4), 124-127. [Google Scholar] [CrossRef]

Vasylieva, T., Bilan, Y., Starchenko, L., Woźniak, A. (2020) Green Intellectual capital for sustainable business model: bibliometric analysis. In Proceedings of the 34th International Business Information Management Association (IBIMA) conference. Retrieved from https://ibima.org/conference/35th-ibima-conference/

Vovchak, O. D., Senyshch, P. M., \& Melnyk, T. V. (2019). «Purging» of the banking system: impacton the key performance indicators of banks. Financial and credit activity: problems of theory and practice, 1(28), 16-25. [Google Scholar] [CrossRef]

Wang, J. L., Hsiung, H. H., \& Xu, J. R. (2019, September). Is the Value-Relevance of IFRS Better than GAAP? An Empirical Study of Taiwan. In Proceedings of the 2019 5th International Conference on Industrial and Business Engineering (pp. 383-388). [Google Scholar] [CrossRef]

Ніязі Ісмаілов, Ph.D, доцент, Азербайджанський державний економічний університет, Республіка Азербайджан

Інноваційні підходи в обліку та аудиті балансової вартості активів: бібліометричний аналіз

Ця стаття присвячена аналізу наукового доробку щодо дослідження питань інноваційних підходів в обліку та аудиті балансової вартості активів. Автор відмітив, доиільність впровадження нового або удосконаленого стандарту бухгалтерського обліку та звітності для врахування балансової вартості активів, особливо в умовах фінансової кризи. Головною метою статті є визначення майбутніх напрямків досліджень питань обліку та аудиту балансової вартості 
активів на основі бібліометричного аналізу тенденції наукових публікацій з означеної тематики. Емпіричне дослідження проведено на основі панельних даних, сфрормованих для вибірки з 714 публікацій. Для аналізу панельних даних автором використано інструментарій програмного забезпечення VOSviewer ma Scopus. За результатами дослідження виявлено висхідну тенденцію публікаційної активності досліджуваних публікацій з 1997 по 1999 роки, з 2007 по 2009 роки та з 2014 по 2017 роки. Крім того, наголошено на зміні тематики наукових досліджень від загальних питань до питань реальної вартості активів, впровадження модифікуючих стандартів звітності та бухгалтерського обліку. Аналіз результатів засвідчив, що у 2018 році кількість наукових публікацій у базі даних Scopus зросла на 1225\% порівняно до 1997 року. При цьому найбільшу кількість публікацій було присвячено аналізу інноваційних підходів в обліку та аудиті балансової вартості активів у наступних галузях знань: Бізнес, управління та бухгалтерський облік; Економіка, економетрика та фінанси; Соціальні науки; Технології. Крім того, найбільша частка вчених, які досліджували дані питання були представниками США, Великобританії, Австралії та Китаю. За результатами встановлено, що у 2019 році значну кількість досліджуваних документів було опубліковано у журналах з високим імпакт-фрактором, а саме: "Contemporary Accounting Research», "Accounting Review», "International Journal Of Accounting», "Managerial Finance», "Accounting And Business Research», тощо. У ході дослідження автор приходить до висновку, що тематика інноваційних підходів в обліку та аудиті балансової вартості активів насправді відповідає поточним тенденціям сучасного обліку, фінансів, управління та аудиту. Результати проведеного бібліометричного аналізу за допомогою інструментарію VOSviewer дозволили визначити 6 кластерів тематичної близькості досліджуваних публікацій. Зокрема, найбільші з них включають наступні ключові слова: 1) бухгалтерська інформація, реальна вартість, ффінансова звітність, облік реальної вартості, фрірма, вартість, нематеріальні активи, інтелектуальний капітал, тощо; 2) витрати, облік витрат, метод бухгалтерського обліку, вартість активів, оцінка активів, амортизація, аналіз витрат та вигод, баланс, тощо; 3) кримінальних аспекти релевантності вартості, балансова вартість, балансова вартість власного капіталу, оцінка власного капіталу, прибуток, дивіденди, тощо. Враховуючи отримані результати дослідження, автором зроблено висновок, щодо актуальності проведення подальщих досліджень питань процесу прийняття фрінансових та управлінських рішень на основі порівнянні балансової та ринкової вартостей для прогнозування майбутньої (реальної) вартості активів або навіть організації.

Ключові слова: балансова вартість, вартість активів, звітність, фінансова звітність, аудит, інноваційні підходи.

Manuscript received: 03.02.2020

(C) The author(s) 2020 This article is published with open access at Sumy State University. 